\title{
Introduction
}

\author{
Delia Chiaro \\ University of Bologna \\ delia.chiaro@unibo.it
}

\section{Giselinde Kuipers}

University of Amsterdam

G.m.m.kuipers@uva.nl

This collection of essays began as a project in which the two editors had set out to honour the career and scholarship of Christie Davies. From the very beginning, we had envisaged an event in which a lively gathering of friends and colleagues would have presented Christie with this Special Issue, preferably as a surprise and accompanied by due pomp and circumstance. Regrettably, this was not to be. As we were to learn later, already during early work on this manuscript, Christie was living on borrowed time.-Yet, although with enormous sadness the collection has now become in memoriam, the editors would like to underscore that it is still above all, ad honorem. Numerous obituaries have recounted the breadth and the depth of Christie's scholarship and we will not repeat what others have already said. However, we would like to underscore that what emerges from the words of each contributor in this edition, together with feelings of respect and immense awe for his erudition, are above all sentiments of warmth and affection towards a scholar, but primarily towards a friend. To say that Christie was someone who was well loved is a gross understatement. People loved him because he was generous, kind, clever, funny, outspoken and outrageous even, but above all because each individual felt that he or she was his special friend. The more Christie liked you, the more mischievous he would be and the more he would engage in playful aggression at your expense. Pretending he had never heard a song by The Beatles or the Stones (Montreal 2017), responding to drunks who accosted him in the streets of Aberdeen in his best highland Scots (Aberdeen 2016), and baffling north Americans who asked him where he was from by responding "Cymru" (Baltimore 2001) are just three examples of Christie's "naughty boy" persona.

That Christie was a special friend to Jessica Milner Davis surfaces though every word in her essay in which she endeavours to "unmask" him. Davis weaves an elaborate tapestry stretching across over forty years of collaboration and friendship in which she intertwines personal anecdotes with Christie's academic achievements. We learn that the two humour scholars Davis and Davies have far more in common than a homophonic surname. They share a heritage that includes grandfathers from the same town in Yorkshire and a love for playful aggression. Davis asserts that "taking the mickey" is an essential part of Australian culture - a trait that Christie had adopted to a tee - see, for example, the "parking" episode recounted by Delia Chiaro in which he publicly teases the author for her superior parking skills. The other 
common denominator is an interest in humour surrounding the law and the judiciary. Mocking judges, lawyers and the like was one of Christie's favoured subjects strengthened by the fact that Janetta, his wife, is a well-known solicitor. Davis concludes her paper by suggesting that part of Christie was Australian. However, if Christie might be a contender for Australian citizenship, surely his interest in and love for diverse cultures also makes him a candidate for several other honorary nationalities including Estonian, German, Indian, Italian, Polish and Russian, just to mention a few - not to mention an array of honorary religions too.

It was a suggestion of Jessica Milner Davis to include in this In Memoriam a reprint of an article by Christie Davies himself. "The progress of Australian humour in Britain", paper on Australian humour originally published in 1997, showcases all Christie's qualities as a scholar and a writer. A deeply sophisticated analysis of a seemingly mundane topic - including a long section on vomit humour - the article is carefully argued, based on meticulous empirical research, informed by sociological theory classic and modern, and by deep insight in Australian history and culture. Above all, it is thought-provoking, clever and very witty.

Both Victor Raskin and Salvatore Attardo acknowledge the enormous influence Christie had upon their work; additionally they display their deep fondness and appreciation he inspired in them.

In a similar vein to Davis, Raskin's contribution focuses on the two scholars' "mutual adoration pact that lasted for decades". Two essentialists, their views on humour were intricately linked as each supported the theories of the other. Upon Christie's demise, Raskin posted the phrase "Baruch Dayan Emet" on Facebook. The closest translation to this is "blessed is the true judge", meaning, "How can we understand the ways of God?" Jews utter this phrase when someone has died but what is meaningful is the ritual of actually saying the phrase. It is poignant that Raskin is paying Christie the highest compliment by using the ritual Jewish expression on the death of a member of the Jewish community thus making him an honorary Jew. Attardo's contribution is also an expression of deep affection. With great fondness and pride, Attardo recalls their intellectual "disagreements" in particular with regard to Christie's dislike of Logical Mechanisms in the GTVH, something also taken into consideration by Wladysław Chłopicki and Dorota Brzozowska. With his tongue firmly in his cheek, Attardo references Christie's "vests with many pockets". These thick padded waistcoats have a number of zipped-up pouches from which anything and everything imaginable would emerge. It was in July 2017, in an Israeli restaurant in Montreal, where eschewing what was on offer, Christie would surreptitiously retrieve dates from a pocket and nonchalantly pop them into his mouth.

As one would imagine, several essays pivot around one of Christie's favourite topics, namely jokes and their targets. Giovannantonio Forabosco examines the whys and wherefores of the carabiniere as the underdogs of traditional jokes that circulate within Italy. Christie notoriously argued (1990) that this military police force is targeted because it attracted meridionali, namely southerners from the poorer, rural southern regions of the peninsula, who chose the profession as it provided secure work. Northern Italians saw the arrival of these newcomers as peripheral others, in the same way as the English saw the Irish, North Americans the Poles etc. Hence the carabiniere joke cycle was born. Forabosco however argues that such is the lingua-cultural gap between north and south that it is likely locals really considered these police officers to be stupid as they may not have understood, let alone be conversant in, the local northern varieties of Italian thus making them appear stupid. Joke cycles like these may well be shifting away from their traditional oral form and moving into digital spaces where they spread via smart technology. 
Delia Chiaro also looks at recent jokes that target Italians by especially focussing on internet memes. These memes appear to be a progression from the classic verbal trope regarding bad soldiers or hirsute women, into a visually anchored message circulated by means of mobile technology and in the worst possible taste of which Christie would undoubtedly have approved. The stupidity of those inhabiting the Polish periphery are examined by Wladysław Chłopicki and Dorota Brzozowska. Their article departs from an amicable scholarly disagreement with Christie: it is always bad to be the target of a stupidity joke? Chłopicki and Brzozowska challenge this assumption, showing that in jokes about Polish highlanders, the "stupid" highlanders emerge as superior in many respects to the educated city-dwellers. Liisi Laineste and Anastasiya Fiadotava present a diachronic overview of ethnic jokes in Belarus and Estonia bringing the reader right up to date with examples of internet memes. Despite strong evidence to the contrary, Christie was not convinced that jokes had now widely "gone viral" via smart phones and tablets and stubbornly stuck to jokes in more traditional oral and written forms for his own research.

On a slightly different tack, but in line with Christie's work, Anna T. Litovkina examines anti-proverbs and wellerisms that gently tease the institution of marriage. While the two tropes are not jokes stricto sensu, they do remain firmly within the territory of verbally expressed humour in technical terms, while reflecting social values too. Christie had written at length about the playful aggression emerging from jokes targeting a wide range of institutions including the church, the judiciary, marriage and even mothers-in-law.

The contributions of psychologists Willibald Ruch and Jennifer Hofmann, computer scientist Julia Rayz Taylor and linguist/computer scientist Victor Raskin highlight another characteristic of Christie's work: his affinity for, and strong advocacy of scholarly rigour in the study of humour. Christie's work was always based on empirical data, using a strict comparative methodology. Both Rayz Taylor and Raskin show that this made his approach - surprisingly quite compatible with their attempts to construct a formal theory of humour. Rayz Taylor most explicitly discusses how Christie's insights and his data sets might help advance a computational theory of humour. Ruch and Hofmann, present a comparative analysis of humour appreciation across media and humorous forms. As in Christie's comparative work, their comparative analysis reveals both the elements of humour that remain constant, and the elements that vary, thus advancing our knowledge of humour - while acknowledging its cultural specificity.

From the perspective of Speech Act Theory, Debra Aarons and Marc Mierowsky explore how stand-up comedians create a relationship in which the audience engages with them and sees matters from their viewpoint. Christie believed that jokes are a thermometer of a society but never a thermostat. In other words, jokes could criticise a society but not change it. In fact, Villy Tsakona aptly quotes Christie in her essay "Jokes are the aspirin of the people taken to suspend political pain; jokes cannot cure the pain" (Davies 2011: 248) and then goes on to explore the function of political jokes during the recent Greek financial crisis. Conversely, Aarons and Mierowsky suggest that charged stand-up humour may well awaken the social consciousness in audiences in the hope that this awareness might lead to change.

Christie was a great admirer of Germany. At a dinner party at the home of one of the editors, he made no secret of singing the praises of a tall dark German guest, Andreas. Christie waxed lyrically about how clever and how handsome the Germans were while knowing that his playful aggression would annoy the wife of a short fair Sicilian also present at table. In addition, sociolinguistics classes at the University of Bologna would not be the same without reading Christie's defence of German as the candidate for the single language of Europe. "The might of the German army, the spending power of German tourists and the untranslatability of abstract 
nouns have placed German at the very heart of Europe and of what it is to be a European" (Davies n.d.) writes Christie as he overtly slates the French language. How he would have much appreciated Christian F. Hempelmann's critique of Schmidt-Hidding's famous lexical field study of humour words in German and English. Hempelmann contextualizes SchmidtHidding's diamond-shaped diagram of dimensions of humour terminology within the historical context from which it emerged suggesting that over and above the deeply flawed methodology upon which the argument of Schmidt, who renames himself Schmidt-Hidding after 1944, was based, the ideological direction of the study was strongly influenced by its authors' national socialist ideology.

Hempelmann's analysis reiterates a final central point in Christie's work: again and again, he argued that humour is a form of communication, or maybe a form or reasoning, sui generis. Humour cannot be reduced to a single, unambiguous sentiment or statement. Thus, Christie famously argued that humour is "playing with aggression", often (though not necessarily) unrelated to real aggression or hostility. Consequently, he vehemently argued against what he saw as overly normative analyses of ethnic and racial jokes. While this generally brought him in conflict with scholars who positioned themselves on the left or liberal side of the political spectrum, he equally disapproved of such a one-dimensional humour analysis on the political (far) right, as the case of Smidt-later-Hidding.

Christie shared this sceptical attitude towards political or overly literal interpretations of humour with folklorist Elliott Oring. In his analysis of a joke cycle about J.Golden Kimball, a devout though rather foul-mouthed Mormon missionary, Oring explicitly discusses the question guiding Christie's work: why do people joke about some things - when they could also, for instance: talk, whisper, gossip, rage, weep, rejoice. Oring rejects both the notion that jokes is a release of aggression, as well as the Freudian notion that jokes are a "safety valve". Instead, Oring writes "I have always thought of jokes more as a philosophy than therapy-as commentary rather than catharsis." We believe the Christie would have approved and embraced this great enthusiasm. It might serve as a motto for his entire magnificent oeuvre.

\section{References}

Davies C. (1990). Ethnic Humour around the World. A Comparative Analysis, Bloomington: Indiana University Press.

Davies, C. (2011). Jokes and Targets. Bloomington: Indiana University Press.

Davies, C. (no date). 'Towards a single European language'. Unpublished paper. 